\title{
Offshoring and Volatility:
}

\section{Evidence From Mexico’s Maquiladora Industry}

\author{
Paul R. Bergin \\ University of California, Davis, and NBER \\ Robert C. Feenstra \\ University of California, Davis, and NBER \\ Gordon H. Hanson \\ University of California, San Diego, and NBER
}

August, 2008

\begin{abstract}
:
This paper studies the second-moment properties of offshoring, the arrangement whereby firms carry out particular stages of production abroad. It documents a new empirical regularity: maquiladora industries in Mexico that are associated with U.S. offshoring experience fluctuations in employment that are twice as volatile as the corresponding industries in the U.S. This finding is not attributable simply to higher volatility in the overall Mexican economy, nor to the smaller size of Mexico’s industries compared to U.S. counterparts.

JEL classification: F1
\end{abstract}

P. Bergin / Department of Economics / University of California at Davis/ One Shields Ave. / Davis, CA 95616 USA prbergin@ucdavis.edu, ph (730) 752-8398,fax (730) 752-9382.

G. Hanson / University of California, San Diego / 9500 Gilman Dr., MC: 0519 La Jolla, CA 92093-0519 USA, gohanson@ucsd.edu, ph (1058) 822-5087,fax (1058) 534-3939.

R. Feenstra / Department of Economics / University of California at Davis/ One Shields Ave. / Davis, CA 95616 USA rcfeenstra@ucdavis.edu, ph (730) 752-7022, fax (730) 752-9382.

We thank Thomas Chaney, Fabio Ghironi and seminar participants at the NBER Summer Institute 2007, ASSA 2007 meetings in Chicago, UC San Diego, Carnegie Mellon University, Princeton University, University of Colorado, University of Paris, University of Southern California, the International Monetary Fund and Academia Sinica in Taipei for helpful comments. 
Offshoring, the arrangement whereby firms carry out particular stages of production abroad, has grown over the last fifteen years to become an important part of the trade relationship between the U.S. and Mexico. It is also of growing importance for trade between the E.U. and emerging economies in Europe, and in global trade with China. In Mexico, employment in export assembly plants engaged in production for foreign firms grew ten-fold from 0.12 million in 1980 to 1.2 million in 2006. The sector accounts for just under 3 percent ofMexico's total GDP, 20 percent of Mexican manufacturing value added, and nearly half of the country's exports. While Mexican officials have hailed the export assembly plants for their contribution to economic growth, some have also complained that the sector is fickle and subject to excessive volatility. ${ }^{1}$ The assembly plants, known as maquiladoras, are seen as a channel by which the U.S. exports to Mexico a portion of its employment fluctuations over the business cycle. This phenomenon is beginning to be investigated in the literature on real business cycles across countries. Our paper is unique in focusing on the maquiladora sector and on cross-country comparisons of volatility. ${ }^{2}$

We begin by documenting the variance in offshoring industries in Mexico. These industries are composed of maquiladoras which U.S. and other foreign firms use to assemble inputs into final outputs. The data cover Mexico's four largest offshoring industries, which together account for three quarters of maquiladora production in the country: apparel,

\footnotetext{
${ }^{1}$ See for example the news account of how the Mexican car industry is highly susceptible to fluctuations in demand for American brand automobiles in Marla Dickerson (2005).

${ }^{2}$ Ariel Burstein, Johann Kurz, and Linda Tesar (2008) study the implications of multinational production for international macroeconomic comovement; as such, their focus is on covariances across countries, rather than on comparing variances, which is our focus. For other work on intermediate inputs and business cycle synchronization see Ayhan M. Kose and Kei-Mu Yi (2001, 2006) and Steve Ambler, Emanuela Cardia, and Christian Zimmerman (2002). See also David Thesmar and Mathias Thoenig (2007) on vertical separation and employment and sales volatility in French firms.
} 
transportation equipment, computers and electronics, and electrical machinery. We match these industries to their counterparts in the United States. The main empirical result is that in all four maquiladora industries the volatility of economic activity in Mexico is significantly higher than in the U.S.; averaging over the four industries, volatility in Mexico is twice as high as in the U.S.

One might suspect that this finding simply reflects higher volatility in the Mexican economy overall. That conjecture is not true for employment volatility, which is lower in Mexico. A second conjecture might be that higher volatility in Mexico reflects the smaller size of industries in Mexico. However, our results are robust to comparing Mexican industries with the more similarly sized industries of U.S. border states. ${ }^{3}$

Finally we decompose this effect into its extensive and intensive margins, where the extensive margin is measured using data on the number of plants operating each month in the maquiladora sector, and the intensive margin is measured using data on average employment per plant. Volatility is present along both of these margins.

${ }^{3}$ A third conjecture might be that labor-market institutions differ between the countries, such that it is easier to hire and fire employees in Mexico. However, when Juan C. Botero et al. (2004) rank countries in terms of job security laws restricting the hiring and firing of workers, Mexico ties for the most regulated among the 85 countries in the sample, whereas the U.S. ranks as the fifth least regulated economy in this respect; these data are used in the analysis of volatility and comparative advantage by Alejandro Cunat and Marc J. Melitz (2007). We also see this contrast in labor market flexibility reflected in our employment data discussed below, in which volatility of employment in overall Mexican manufacturing is lower than that for U.S. overall manufacturing. In Mexico, labor unions are active in maquiladoras and other manufacturing establishments, both of which are subject to Mexican labor law (Rafael Otero and Jose A. Pagan, 2002). In practice, collective bargaining agreements in maquiladoras are seen as less restrictive than in the rest of Mexican manufacturing, in that job classifications tend to be wider and firms tend to have greater leeway in establishing pay-for-performance schemes (David Fairris, 2003). At the same time, the decline in unionization in Mexican manufacturing, which has been ongoing since the 1980s, is less evident among maquiladoras. The net effect of more flexible collective bargaining agreements but more stable union presence appears to be that differences in labor relations between maquiladoras and other Mexican manufacturing firms are relatively small. 
Section I of the paper describes relevant background of the maquiladora sector, section II presents the main results characterizing employment volatility, section III decomposes the effect into intensive and extensive margins, and section IV concludes.

\section{The Maquiladora Sector}

Offshoring by the U.S. to Mexico generally takes the form of U.S. firms producing parts and components, exporting these intermediate inputs to Mexico to be assembled or processed into final goods, and re-importing the finished products. U.S. firms tend to specialize in R\&D, component production, marketing, and other headquarters activities, while Mexican plants - the maquiladoras - tend to specialize in assembly services. ${ }^{4}$ Mexico is among the most important locations for offshoring by U.S. firms and the U.S. is by far and away Mexico's largest trading partner. Over the period 2000-2003, the United States was the source country for 73.4 percent of the inputs imported by maquiladoras in Mexico and maquiladora exports back to the United States were equal to 5.3 percent of U.S. industry shipments (U.S. International Trade Commission, 2005). ${ }^{5}$ Maquiladoras have become an integral part of the Mexican economy, with

\footnotetext{
${ }^{4}$ The Mexican government measures imports and exports by registered export-assembly plants in Mexico. Under Mexican trade policy, firms that export their output do not have to pay duties on any imported intermediate inputs used in production. To obtain duty-free status, a firm must register with the government. While under the North American Free Trade Agreement imports from the United States are not subject to duties in Mexico, imports from most other countries are. As a result, the vast majority of export-assembly plants in Mexico are registered. (Strictly speaking, export-assembly plants in Mexico may be registered either as maquiladoras or as PITEX (Program for Temporary Imports of Articles to be Exported) companies (see http://www.economia.gob.mx/). Only the former appear in our data. In 2003, maquiladora exports to the United States were 2.2 times those by PITEX companies.)

${ }^{5}$ These figures apply to the four core offshoring industries, described in the text. Comparing U.S. imports from Mexico to U.S. industry output may give a deceptive sense of the size of Mexico's maquiladora sector relative to U.S. manufacturing. U.S. imports from Mexico include a substantial component of U.S. value added, in the form of the intermediate inputs produced in the United States and sent to Mexico for further processing. As an alternative measure of relative size, one might examine value added in the two countries. Over the period 2000-2003, the ratio
} 
their share of national manufacturing employment rising from 4.1 percent in 1980 to 24.5 percent in 2004 (Gordon Hanson, 2007).

Mexico first began to allow export assembly plants to operate in the country in the 1960s. The maquiladora sector did not reach an appreciable size until the government relaxed restrictions on inbound foreign investment in the 1980s. Initially, U.S. firms offshoring to Mexico received favorable tariff treatment under the HS9802 provision of the U.S. tariff code (Robert Feenstra, Gordon Hanson, and Deborah Swenson, 2000). Under HS9802, U.S. firms that manufacture components at home and have them processed into final goods abroad pay duties on the foreign value-added only when the goods are brought back into the United States. The North American Free Trade Agreement (NAFTA) ended special tariff treatment for U.S. firms offshoring to Mexico. But it did not slow growth in production sharing. Growth in real value added by maquiladoras accelerated after NAFTA was implemented, roughly tripling between 1994 and 2005. Far from removing the incentive for Mexico to specialize in assembly services, NAFTA freed resources Mexico had devoted to domestic production to move into export assembly.

Most offshore production by U.S. firms in Mexico occurs in one of four industries: apparel, electronic accessories (including computer parts and electronic circuitry), electrical machinery (including televisions and other small domestic appliances), and transport equipment and parts (primarily motor vehicles). Over 1990 to 2005 these four industries accounted for three-quarters of employment in the maquiladora sector. These industries are amenable to global production sharing because firms need not perform all stages—R\&D, component production, final

of value added in Mexico's maquiladoras to value added in U.S. manufacturing was 0.034 in the four core offshoring industries, based on annual data (U.S. International Trade Commission, 2005). 
assembly_-in the same location, and the stages vary in their factor intensities, giving multinational firms an incentive to locate labor-intensive activities in low-wage countries.

\section{Volatility in Employment}

As a measure of volatility, we shall focus on the relative variance of employment in U.S. manufacturing industries and the plants to which they offshore production in Mexico. ${ }^{6}$ This variance is computed using the monthly employment of production workers, which is available for both countries. We match Mexico’s four primary maquiladora industries (assembly of apparel items; electronic materials and accessories, including computer parts; assembly of electrical machinery and equipment; and construction and assembly of transport equipment and parts) with their closest U.S. three-digit industry matches (apparel manufacturing, NAICS 315; computer and electronic product manufacturing, NAICS 334; electrical equipment, appliance, and component manufacturing, NAICS 335; and transportation equipment manufacturing, NAICS 336). Data are available beginning in $1993 .^{7}$ However, in late 1994 there was a large depreciation of the peso, as capital fled Mexico, and in 1995 aggregate output dropped sharply. Given the exposure of the maquiladora sector to exchange-rate fluctuations, including the pesocrisis years in our sample could make volatility in Mexico’s maquiladora industries seem artificially high. To avoid this problem, the analysis is limited to the period 1996-2005.

To provide a visual sense of the relative variation in industry activity in the two countries, Figure 1 plots the production-worker employment for the four core maquiladora industries over the sample period. To remove seasonal fluctuations and time trends, each series is seasonally

\footnotetext{
${ }^{6}$ In results available on request, we have confirmed that similar findings obtain when using the wage bill for production workers instead of employment.

${ }^{7}$ Data for Mexico’s maquiladora industries go back to 1990. However, data on Mexico's overall manufacturing sector is only available from 1993 forward, owing to a change in the construction of the series in that year.
} 
adjusted and HP filtered (with smoothing parameter 14400). In each industry, employment in Mexico is substantially more volatile than in the United States. Table 1, which shows the ratio of the standard deviations for the production worker employment in Mexican and U.S. industries, reinforces this perception. In each industry, the standard deviation of Mexican employment is greater than in the United States, with the Mexico-U.S. ratio averaging 2.3 over the four industries.

\section{Table 1. Relative Volatility in Mexico and U.S. Offshoring Industries: Production Worker Employment}

\begin{tabular}{cccccc}
\hline & & $\begin{array}{c}\text { Electrical } \\
\text { Machinery }\end{array}$ & $\begin{array}{c}\text { Computer \& } \\
\text { Electronics }\end{array}$ & $\begin{array}{c}\text { Transport } \\
\text { Equipment }\end{array}$ & Average \\
\hline $\begin{array}{c}\text { Standard Deviations, Employment (percent) } \\
\sigma\left(\mathrm{L}_{\mathrm{i}}^{*}\right) \text { (Mex. Industry) }\end{array}$ & 4.52 & 4.34 & 5.95 & 2.96 & 4.44 \\
$\sigma\left(\mathrm{L}_{\mathrm{i}}\right)$ (U.S. Industry) & 1.88 & 1.68 & 2.80 & 1.38 & 1.94 \\
$\sigma\left(\mathrm{L}^{*}\right)$ (Mex. Aggregate Manufacturing) & 0.89 & 0.89 & 0.89 & 0.89 & 0.89 \\
$\sigma(\mathrm{L})$ (U.S. Aggregate Manufacturing) & 1.07 & 1.07 & 1.07 & 1.07 & 1.07 \\
$\sigma\left(\mathrm{L}_{\mathrm{i}}^{*}\right) / \sigma\left(\mathrm{L}_{\mathrm{i}}\right)$ & 2.40 & 2.58 & 2.13 & 2.14 & 2.31 \\
$\sigma\left(\mathrm{L}^{*}\right) / \sigma(\mathrm{L})$ & 0.83 & 0.83 & 0.83 & 0.83 & 0.83 \\
& & & & & \\
\hline Correlations, Employment & & & & & \\
$\operatorname{corr}\left(\mathrm{L}_{\mathrm{i}}^{*}, \mathrm{~L}_{\mathrm{i}}\right)$ & 0.49 & 0.43 & 0.66 & 0.45 & 0.51 \\
$\operatorname{corr}\left(\mathrm{L}^{*}, \mathrm{~L}\right)$ & 0.78 & 0.78 & 0.78 & 0.78 & 0.78 \\
$\operatorname{corr}\left(\mathrm{L}_{\mathrm{i}}^{*}, \mathrm{~L}^{*}\right)$ & 0.56 & 0.71 & 0.62 & 0.68 & 0.64 \\
$\operatorname{corr}\left(\mathrm{L}_{\mathrm{i}}, \mathrm{L}\right)$ & 0.66 & 0.86 & 0.88 & 0.63 & 0.76 \\
\hline
\end{tabular}

\section{Notes:}

The top potion of the table shows standard deviations (in percent) for the production-worker employment in specific Mexico and U.S. offshoring industries, and in Mexico and U.S. aggregate manufacturing, and the ratios of these standard deviations. Each series is in log values, seasonally adjusted, and HP filtered. Data are monthly from 1996 through 2005. The bottom portion of the table shows correlations between the various employment series. 
One simple reason that employment in Mexican industries could be more volatile than their U.S. counterparts is because at an aggregate level the Mexican economy is also more volatile than the U.S. economy. That reasoning does not apply for employment, however, since as shown in Table 1, employment of production workers in all manufacturing in Mexico has a lower monthly standard deviation than in the United States. ${ }^{8}$ This may reflect the finding in Botero et al. (2004) that Mexico has more restrictive laws regarding employment security (see note 3).

Table 2. Size of Offshoring Industries in Mexico and the U.S.

\begin{tabular}{|c|c|c|c|c|c|}
\hline \multirow[b]{2}{*}{ NAICS } & \multirow[b]{2}{*}{ Industry } & \multicolumn{4}{|c|}{ Thousands of employees (mean 2000-2005) } \\
\hline & & Mexico & U.S. & Texas & California \\
\hline & All maquiladoras (Mexico) & $1,151.00$ & -- & -- & -- \\
\hline & All manufacturing (United States) & -- & $15,336.70$ & 955.5 & $1,649.00$ \\
\hline 315 & Apparel & 230.8 & 356.9 & -- & 97.4 \\
\hline 334 & Computer \& Electronics & 265.6 & $1,512.30$ & 132.9 & 366.6 \\
\hline 335 & Electrical machinery & 100.2 & 497.5 & 20.0 & 38.5 \\
\hline 336 & Transport equipment & 240.7 & $1,855.80$ & 85.2 & 137.5 \\
\hline
\end{tabular}

Source: U.S. Bureau of Economic Analysis, Regional Economic Information System, http://www.bea.gov/bea/regional/reis/; Mexico’s National Institute for Statistics, Geography, and Informatics (INEGI), http://www.bea.gov/bea/regional/reis/.

\footnotetext{
8 This conjecture does hold for the wage bill, but the extra volatility found in the wage bill for Mexican maquiladora industries exceeds that found in Mexican manufacturing. The ratio of the wage bill in Mexico to that in the U.S. is 2.0 for offshoring industries and 1.5 for manufacturing overall.
} 
A second reason for volatility to be higher in the Mexican maquiladora industries is that they are smaller than the U.S. industries, so with idiosyncratic shocks across plants, U.S. employment may be smoothing out shocks. To investigate the size differences between the Mexican and U.S. industries, Table 2 reports employment in each industry, showing that in two of the four industries the U.S. is indeed much larger. We can deal with these size disparities by reducing the geographic coverage of the U.S. series. The vast majority of maquiladoras in Mexico are located in Mexican border cities and many are linked to production operations on the U.S. side of the border (Feenstra, Hanson, and Swenson, 2000). This makes U.S. border states a natural geographic unit to which to compare Mexican maquiladora industries.

In Tables 2 and 3, we compare Mexican industries to their counterparts in California and Texas, the two U.S. border states for which industry data are available. ${ }^{9}$ At the state level, the only series available for three-digit industries is total employment, including production and nonproduction workers. Table 2 shows that employment in industries in California and Texas is similar in scale to Mexican industries. Table 3 shows that standard deviations and their ratios based on state employment data are broadly similar to those obtained for national data: the four offshoring industries are at least 79 percent more volatile in Mexico than in California, and 64 percent more volatile than in Texas, whereas overall Mexican manufacturing employment is less volatile than in either state. We conclude that regardless of the comparison case, the maquiladoras have substantially greater volatility than their corresponding industries in the U.S., or than overall manufacturing.

\footnotetext{
${ }^{9}$ The small number of plants in three-digit manufacturing industries in Arizona and New Mexico makes industry-level data for these states subject to disclosure restrictions.
} 
Table 3. Relative Volatility in Mexico and U.S. Offshoring Industries:

Total Employment at the U.S. State Level

\begin{tabular}{|c|c|c|c|c|c|}
\hline & Apparel & $\begin{array}{c}\text { Electrical } \\
\text { Machinery }\end{array}$ & $\begin{array}{c}\text { Computer \& } \\
\text { Electronics } \\
\end{array}$ & $\begin{array}{l}\text { Transport } \\
\text { Equipment }\end{array}$ & Average \\
\hline & \multicolumn{5}{|c|}{ National Level } \\
\hline$\sigma\left(\mathrm{L}_{\mathrm{i}}^{*}\right)$ (Mex. Industry) & 4.47 & 4.11 & 5.50 & 2.73 & 4.20 \\
\hline$\sigma\left(\mathrm{L}_{\mathrm{i}}\right)$ (U.S. Industry) & 1.58 & 1.44 & 2.38 & 1.05 & 1.61 \\
\hline$\sigma\left(L^{*}\right)$ (Mex. Aggregate Manufacturing) & 0.77 & 0.77 & 0.77 & 0.77 & 0.77 \\
\hline$\sigma(\mathrm{L})$ (U.S. Aggregate Manufacturing) & 0.96 & 0.96 & 0.96 & 0.96 & 0.96 \\
\hline$\sigma\left(\mathrm{L}_{\mathrm{i}}^{*}\right) / \sigma\left(\mathrm{L}_{\mathrm{i}}\right)$ & 2.83 & 2.85 & 2.31 & 2.60 & 2.65 \\
\hline \multirow[t]{2}{*}{$\sigma\left(\mathrm{L}^{*}\right) / \sigma(\mathrm{L})$} & 0.80 & 0.80 & 0.80 & 0.80 & 0.80 \\
\hline & \multicolumn{5}{|c|}{ California } \\
\hline$\sigma\left(\mathrm{L}_{\mathrm{i}}^{*}\right)$ (Mex. Industry) & 4.47 & 4.11 & 5.50 & 2.73 & 4.20 \\
\hline$\sigma\left(\mathrm{L}_{\mathrm{i}}\right)$ (Cal. Industry) & 2.25 & 2.29 & 2.57 & 1.3 & 2.10 \\
\hline$\sigma\left(\mathrm{L}^{*}\right)$ (Mex. Aggregate Manufacturing) & 0.77 & 0.77 & 0.77 & 0.77 & 0.77 \\
\hline$\sigma(\mathrm{L})$ (Cal. Aggregate Manufacturing) & 1.37 & 1.37 & 1.37 & 1.37 & 1.37 \\
\hline$\sigma\left(\mathrm{L}_{\mathrm{i}}^{*}\right) / \sigma\left(\mathrm{L}_{\mathrm{i}}\right)$ & 1.99 & 1.79 & 2.14 & 2.10 & 2.01 \\
\hline \multirow[t]{2}{*}{$\sigma\left(\mathrm{L}^{*}\right) / \sigma(\mathrm{L})$} & 0.56 & 0.56 & 0.56 & 0.56 & 0.56 \\
\hline & \multicolumn{5}{|c|}{ Texas } \\
\hline$\sigma\left(\mathrm{L}_{\mathrm{i}}^{*}\right)$ (Mex. Industry) & 4.47 & 4.11 & 5.50 & 2.73 & 3.09 \\
\hline$\sigma\left(\mathrm{L}_{\mathrm{i}}\right)$ (Tex. Industry) & na & 2.48 & 3.12 & 1.66 & 2.42 \\
\hline$\sigma\left(L^{*}\right)$ (Mex. Aggregate Manufacturing) & 0.77 & 0.77 & 0.77 & 0.77 & 0.77 \\
\hline$\sigma(\mathrm{L})$ (Tex. Aggregate Manufacturing) & 1.16 & 1.16 & 1.16 & 1.16 & 1.16 \\
\hline$\sigma\left(\mathrm{L}_{\mathrm{i}}^{*}\right) / \sigma\left(\mathrm{L}_{\mathrm{i}}\right)$ & na & 1.66 & 1.76 & 1.64 & 1.69 \\
\hline$\sigma\left(\mathrm{L}^{*}\right) / \sigma(\mathrm{L})$ & na & 0.66 & 0.66 & 0.66 & 0.66 \\
\hline
\end{tabular}

\section{Notes:}

The table follows the same format as the top portion of Table 1, but uses total employment rather than production-worker employment. Percent.

n.a. indicates this industry is not available for that state. 


\section{Volatility in the Extensive Margin}

We next investigate how volatility in maquiladora employment is allocated between the intensive and extensive margins. The greater relative volatility in employment in Mexico’s maquiladora industries could be due to changes in scale in existing plants or to plants entering and existing production. We use data on the number of plants operating each month in the maquiladora sector and the average employment per plant. Research on exporting plants in other countries has found that the sunk costs of becoming an exporter are quite high, with much smaller continuation costs of exporting. For example, Sanghamitra Das, Mark J. Roberts and James R. Tybout (2007) estimate that the sunk costs of becoming an exporter for Colombian plants are on the order of $\$ 1$ million, or between 20 percent and 40 percent of the annual export value (with continuation costs around 1 percent). Those values suggest that movement in and out of exporting status would operate in a lumpy fashion, and only in response to large shocks. Our data on the maquiladora plants differs from other country samples in that all of these plants are

involved in export assembly for foreign firms, so plant entry and exit is the same as the exporting decision.

The monthly standard deviation in the number of plants (logged, deseasonalized and HP filtered) ranges between 2.1 percent for electrical machinery to 5.2 percent for apparel, with an average of 3.1 percent over the four industries. That variation is about two-thirds as much as the monthly standard deviation in employment, and there is a positive correlation between the number of plants and employment. We can evaluate the relationship between aggregate employment and the number of plants more formally along the lines of Jonathan Eaton, Samuel Kortum and Francis Kramarz (2004), using the identity:

$$
N_{i t} \times \frac{E_{i t}}{N_{i t}} \equiv \frac{E_{i t}}{E_{t}} \times E_{t},
$$


where $E_{i t}$ is employment in industry $i$ at time $t, N_{i t}$ is the number of plants in industry $i$ at $t$, and $E_{t}$ is aggregate employment in Mexico at $t$. From this identity we specify two regression equations:

$$
\ln N_{i t}=\alpha_{0}+\alpha_{1} \ln \frac{E_{i t}}{E_{t}}+\alpha_{2} E_{t}+\varepsilon_{i t}
$$

and

$$
\ln \frac{E_{i t}}{N_{i t}}=\beta_{0}+\beta_{1} \ln \frac{E_{i t}}{E_{t}}+\beta_{2} E_{t}-\varepsilon_{i t}
$$

By the logic of least squares, $\alpha_{0}+\beta_{0}=0, \alpha_{1}+\beta_{1}=1$ and $\alpha_{2}+\beta_{2}=1$. The relative magnitude of the coefficients identifies how aggregate shocks affect the number of plants (the extensive margin) and employment per plant (the intensive margin).

Table 4: Adjustment in the Maquiladora Industry: Extensive Margins

\begin{tabular}{ccc} 
& $\begin{array}{c}\text { Number of } \\
\text { plants }\end{array}$ & $\begin{array}{c}\text { Employment } \\
\text { per plant }\end{array}$ \\
\hline & $(1)$ & $(2)$ \\
Industry share of & 0.376 & 0.624 \\
aggregate employment & $(0.163)$ & $(0.163)$ \\
& & \\
Aggregate employment & 0.494 & 0.506 \\
& $(0.052)$ & $(0.052)$ \\
& & \\
$\mathrm{R}^{2}$ & 0.303 & 0.513 \\
$\mathrm{~N}$ & 480 & 480 \\
\hline
\end{tabular}

\section{Notes:}

Columns (1) and (2) show regressions of either the number of plants or employment per plant on total Mexican manufacturing employment and the industry share of manufacturing employment. The sample is the four maquiladora industries in Mexico, with data at a monthly frequency from 1996:1 to 2005:12.

Regressions include controls for industry fixed effects, which are not shown. Standard errors (clustered by industry) are in parentheses. 
Table 4 reports results for this decomposition exercise. All series have been deseasonalized and HP filtered and data are pooled across the four offshoring industries. Controls for industry fixed effects are included in the estimation. In column (1), the estimate for $\alpha_{1}$ is 0.38 and for $\alpha_{2}$ is 0.49 , where both are statistically significant. In response to an increase the share of aggregate employment in an offshoring industry (holding aggregate employment constant) over one-third of adjustment in industry employment occurs at the extensive margin, and in response to an increase in aggregate employment (holding the industry employment share constant) nearly onehalf of adjustment in industry employment occurs at the extensive margin.

\section{Conclusion}

Global production sharing is responsible for a substantial portion of world trade and is the primary means through which many developing countries engage in international commerce. While the expansion of export assembly operations have lead to impressive rates of employment growth in China, Eastern Europe, Mexico, and elsewhere, the implications of global production sharing for the volatility of economic activity has only recently attracted scholarly attention.

In the case of Mexico, we document that the country's maquiladora industries experience fluctuations in economic activity that are twice as volatile as the corresponding industries in the U.S. These fluctuations are not simply byproducts of higher volatility in the overall Mexican economy, nor are they the product of the smaller size of the Mexican industries compared to their U.S. counterparts. We also document that adjustments in the extensive margin account for one-third to one-half of this employment volatility.

The robust empirical regularity that our paper identifies indicates that offshoring has

implications for recipient economies not previously considered. Further, this finding presents a new fact useful for guiding and evaluating theoretical research on offshoring. 


\section{References}

Ambler, Steve, Emanuela Cardia and Christian Zimmerman. 2002. "International Transmission of the Business Cycle in a Multi-Sectoral Model.” European Economic Review, 46(2): 273300 .

Botero, Juan C., Simeon Djankov, Rafael La Porta, Florencio López de Silanes, and Andrei Schleifer. 2004. “The Regulation of labor.” Quarterly Journal of Economics, 119(4): 13391382.

Burstein, Ariel, Johann Kurz, and Linda Tesar. 2008. "Trade, Production Sharing, and the International Transmission of Business Cycles.” Journal of Monetary Economics, 55(4): 775-795.

Cunat, Alejandro and Marc J. Melitz. 2007. "Volatility, Labour Market Flexibility, and the Pattern of Comparative Advantage.” NBER Working Paper 13062.

Das, Sanghamitra, Mark J. Roberts, and James R. Tybout. 2007. “Market Entry Costs, Producer Heterogeneity, and Export Dynamics.” Econometrica 75(3): 837-873.

Dickerson, Marla. 2005. “Big 3’s woes migrate: Mexico’s dependence on assembling cars for U.S. automakers puts pressure on its economy as Detroit loses market share to foreign competitors.” Los Angeles times Business Section, August 21: 1.

Eaton, Jonathan, Samuel Kortum, and Francis Kramarz. 2004. "Dissecting Trade: Firms, Industries, and Export Destinations.” American Economic Review, 94(2): 150-154.

Fairris, David. 2003. "Unions and Wage Inequality in Mexico.” Industrial and Labor Relations Review, 56(3): 481-497.

Feenstra, Robert C., Gordon H. Hanson, and Deborah Swenson. 2000. "Offshore Assembly from the United States: Production Characteristics of the 9802 Program.” In The Impact of International Trade on Wages , ed. Robert C. Feenstra, ed., 85-128. Chicago: University of Chicago Press and the National Bureau of Economic Research.

Hanson, Gordon H. 2007. “Globalization, Labor Income, and Poverty in Mexico.” In Globalization and Poverty, ed. Ann Harrison, 417-456. , Chicago: University of Chicago Press and the National Bureau of Economic Research..

Kose, M. Ayhan and Kei-Mu Yi. 2001. "International Trade and Business Cycles: Is Vertical Specialization the Missing Link?” American Economic Review 91(2): 371-375.

Kose, M. Ayhan and Kei-Mu Yi. 2006. "Can the Standard Real Business Cycle Model Explain the Relation between Trade and Comovement?” Journal of International Economics 68(2): 267295.

Otero, Rafael, and Jose A. Pagan. 2002. “Unions and Job Queuing in Mexico’s Maquiladoras.” Eastern Economic Journal, 28(3): 393-407. 
Thesmar, David and Mathias Thoenig. 2007. "From Flexibility to Insecurity: How Vertical Separation Amplifies Firm-level Uncertainty.” Journal of the European Economic Association, 5(6): 1161-1202.

U.S. International Trade Commission. 2005. Industry Trade and Technology Review, USITC Publication 3762, December/January. 
Figure 1: Employment for Production Workers in Mexico and U.S. Offshoring Industries

(log values, seasonally adjusted and HP filtered)
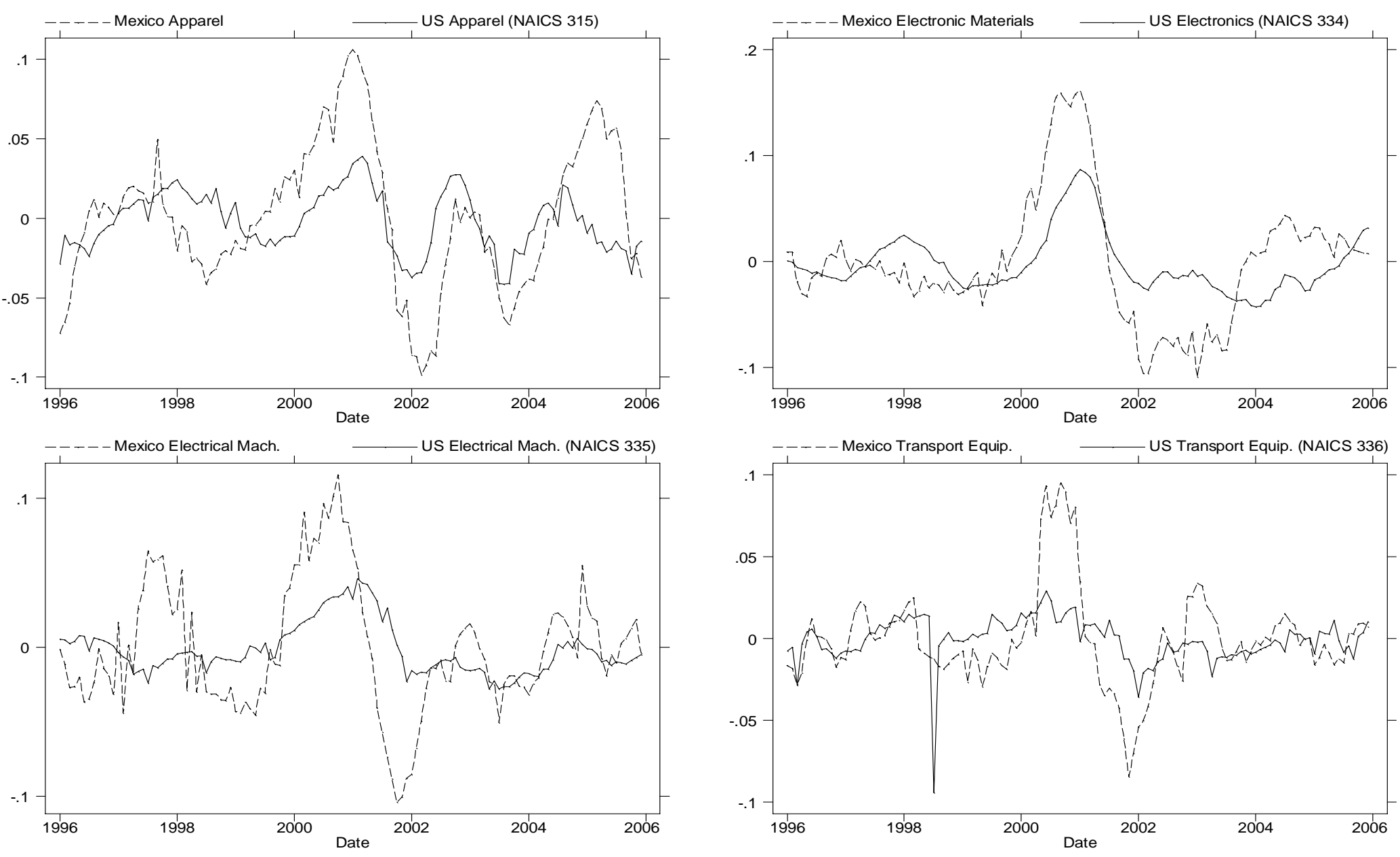